\title{
Making Immigrants Visible in Lampedusa: Pope Francis, Migration, and the State
}

\section{R. Tina Catania}

To cite this article: R. Tina Catania (2015) Making Immigrants Visible in Lampedusa: Pope Francis, Migration, and the State, Italian Studies, 70:4, 465-486

To link to this article: http://dx.doi.org/10.1080/00751634.2015.1120951

曲 Published online: 22 Feb 2016.

Submit your article to this journal ¿

$Q^{1}$

View related articles $\sqsubset$ 


\title{
Making Immigrants Visible in Lampedusa: Pope Francis, Migration, and the State
}

\author{
R. TINA CATANIA \\ Syracuse University
}

In July 2013, the recently elected Pope Francis chose Lampedusa for his first pastoral visit. A tiny island, part of the Sicilian region yet closer to Tunisia than to Italy, Lampedusa has at times become hyper-visible in the media and national discourses surrounding immigration while at other times it is ignored - part of Italy's geographic and social margins. I trace stories of migration to Lampedusa through the objects and speech employed by Pope Francis. I examine the once discarded wooden migrant boats and their transformation into visible representations of migration. During the papal Mass, these sacred, liturgical objects born from trash became part of Pope Francis' visual challenge to the invisibility of migrant deaths. I explore the genealogies of the liturgical objects used at Mass, specifically the altar, chalice, ambo, and ferula, to understand how discourses of migration and religion intersect to challenge Italian state practices of migration management.

KEYWORDS migration, state, Pope Francis, religion, Lampedusa

In May 20II, an old wooden fishing boat from Libya carried migrants from sub-Saharan Africa towards Europe. After being rescued by Italian authorities, its rudder broke as it was being guided into port; crashing into the rocks and cliffs of Lampedusa's shores (see Figure I). No one could foresee that in 20I3, part of that boat would hold the precious blood of Christ. Another boat, this one small and carrying Tunisian migrants to Lampedusa after the Arab Spring of 20II, would later become the altar on which the Vicar of Christ, Pope Francis, would consecrate bread and wine into the body and blood of Christ. The rudders of two more Tunisian boats and the wheel from another Libyan ship would be joined together to create the ambo, or lectern, from where the Gospel of Christ was proclaimed; from where Pope Francis would try and steer human consciousness towards compassion for all human souls, especially migrants, by decrying the globalization of indifference. These objects, central to Pope Francis' visit to the island 


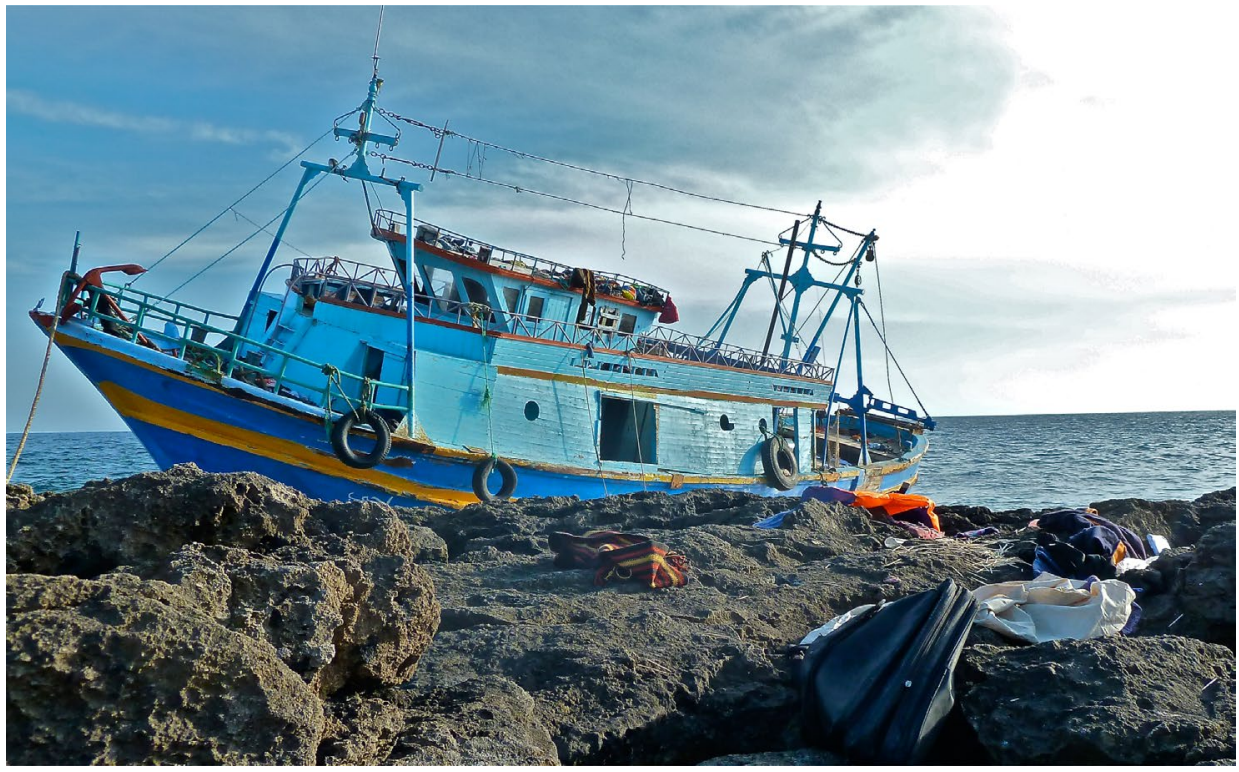

FIGURE 1 The boat which crashed into the rocks of Cavallo Bianco in the early morning of 8 May 2011. Photograph taken the afternoon of 8 May 2011, by Fabio Giovanetti for Archivio Storico Lampedusa.

of Lampedusa in July 20I3, reveal the interconnected stories of migration, geopolitics, religion, and the state for those migrants passing through the island.

Since the mid-I990s, Lampedusa has been a significant point of arrival for migrants and refugees from North African cities. In 2007 and 2008, approximately 42,000 migrants were registered as arriving in Lampedusa and processed through the island's detention centre. Following 2009 bilateral agreements between Italy and Gheddafi in Libya that pushed back migrant boats to African shores, the number of migrants processed through Lampedusa dwindled to approximately $2,300 .{ }^{\mathrm{I}}$ Hailing pushback policies as a success, Roberto Maroni, Minister of the Interior, declared the immigration problem over, and stated that arrivals in Lampedusa had ceased. While numbers had decreased significantly, arrivals continued. Migrants were brought directly to Sicily, however, and, even if they did land in Lampedusa, they were not processed through its detention centre, leading to Lampedusa's low numbers. Following Arab Spring uprisings and government overthrows in Tunisia in 2010 and Libya in $201 \mathrm{I}$, arrivals in Lampedusa reached over $5 \mathrm{I}, 000 .^{2}$ By the end of 2013 , the total number of immigrants arriving in Italy was 42,925 ; of these, I 4,753 had been processed through Lampedusa. ${ }^{3}$

I Ministero dell'Interno, '0297_Lampedusa', (2009), <http://www.interno.gov.it/mininterno/export/sites/default/ it/assets/files/I 5/0297_lampedusa.pdf> [accessed II June 20I5].

2 'Informativa del Governo relativa ai flussi migratori a Lampedusa e conseguente discussione (ore 9,40)', (29

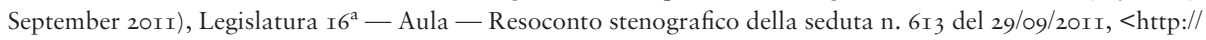
www.senato.it $/ \mathrm{japp} / \mathrm{bgt} / \mathrm{showdoc} /$ frame.jsp?tipodoc $=$ Resaula\&leg= $=\mathrm{I} 6 \& \mathrm{id}=006 \mathrm{I} 6254 \& \mathrm{aj}=\mathrm{no}>[$ accessed II June $2015]$.

3 'Immigrazione: 2.I56 sbarcati a gennaio, Io volte in più dei primi 30 giorni del 20I3', (5 May 20I4), <http://www. interno.gov.it/mininterno/export/sites/default/it/sezioni/sala_stampa/notizie/immigrazione/20I4_02_05_bubbico_ audizione_ue.html_457325499.html> [accessed II June 20I5]. 
What these statistics do not tell us, however, is the complicated history of accoglienza in Lampedusa. Human rights reports have for years documented the poor conditions of Lampedusa's reception centre due to overcapacity and lack of efficient state transfers to other centres on the mainland, ${ }^{4}$ not to mention the treacherous conditions of passing safely through the Mediterranean thanks to agreements with dictatorial governments that have pushed back migrants to Africa and resulted in their jailing and torture. ${ }^{5}$ Even national tragedies like the shipwreck of 3 October 20I3, with the largest death toll to date, did not change the everyday inhumanities of living in the Lampedusa centre. Migrants still slept outside on foam mattresses, dehumanized, waiting months for the state to decide their fate. ${ }^{6}$ EU policies, like Dublin II, restrict their movement and location of asylum claims, preventing those with families in other EU countries from reunification. ${ }^{7}$

These larger (trans)national policies are deeply intertwined with regional and local politics. For example, in 20I2, Lampedusa elected a new mayor, Giusi Nicolini. As former head of Legambiente Lampedusa, she filed multiple charges with the police in 2009

4 Kate Coddington et al., 'Embodied Possibilities, Sovereign Geographies and Island Detention: Negotiating the "right to have rights" on Guam, Lampedusa and Christmas Island', Shima: The International Journal of Research into Island Cultures, 6.2 (20I2): 27-48 (pp. 35-36); Amnesty International, 'Lampedusa, Amnesty International: migliaia di persone in condizioni "agghiaccianti”, (2OII), <http://www.amnesty.it/flex/cm/pages/ServeBLOB. php/L/IT/IDPagina/4693> [accessed 9 August 20II].

5 For respingimento practices and bi-lateral state agreements, see Gabriele Del Grande, Il mare di mezzo: Al tempo dei respingimenti (Torino: Infinito, 2009); Martina Tazzioli, 'Cronologia degli accordi Italia-Tunisia', (December 20II), Storie Migranti, <http://www.storiemigranti.org/spip.php?articleIo04> [accessed February 2, 20I2]. For violence in Libyan migrant jails, see Gabriele Del Grande, 'Fuga da Tripoli: Rapporto Sulle Condizioni dei Migranti di Transito in Libia' (25 October 2007), Fortress Europe, <http://fortresseurope.blogspot.com/2006/or/download-libya-2007-report.html> [accessed Io December 20IO]; 'Bollettino migranti', (2I January 2009), PeaceReporter.net, $<$ http://it.peacereporter.net/articolo/I3833/Bollettino+migrantitalic> [accessed II December 20Io]; Human Rights Watch, 'Stemming the Flow: Abuses Against Migrants, Asylum Seekers and Refugees' Human Rights Watch, I3 September 2006), <http://www.hrw.org/en/reports/2006/o9/I2/stemming-flow-o> [accessed Io December 20I0]. Many of these sites were financed with Italian or EU monies, specifically the jails in Kufrah and Sebha, Libya. For more, see European Commission, 'Technical Mission to Libya on Illegal Immigration: 27 NOV - 6 DEC 2004', (Report, Brussels, Council of Europe, 4 April 2005), <http://www.statewatch.org/news/2005/may/eu-report-libya-ill-imm.pdf> [accessed II June 20I5]; Camera dei Deputati, 'Resoconto stenografico dell'Assemblea: Seduta n. I84 del 5/7/2007', (2007), <http://www.camera.it/_dati/legI $5 /$ lavori/stenografici/sed I $84 /$ s30or.htm > [accessed Io December 2010].

6 For example, photos taken by Scelta Civica deputy Mario Marazziti in October 2013 visually document the animal-like conditions (Famiglia Cristiana, 'Il CPT di Lampedusa, come un canile' (9 October 20I3), <http://www. famigliacristiana.it/fotogallery/il-cie-di-lampedusa-come-un-canile.aspx> (accessed I7 December 20I3.) Similarly, a video taken by a detained immigrant at the centre and leaked to activists and the press just a couple months after the tragic 3 October 2013 shipwreck, which showed immigrants being disinfected for scabies while naked outside, prompted mayor Giusi Nicolini to compare the images to those of un 'campo di concentramento', Corriere della Sera, <http://www.corriere.it/cronache/I3_dicembre_I7/lampedusa-fila-nudi-freddo-disinfestazione-choc-migranti-fddc59a8-67I8-IIе3-boa6-6ra5of6cb30I.shtml> [accessed I7 December 20I3].

7 Dennis Broeders, 'Tracing, Identifying and Sorting: The Role of EU Migration Databases in the Internal Control on Irregular Migrants', in Migration and Mobility in Europe: Trends, Patterns and Control, ed. by Heinz Fassmann, Max Haller, and David Lane (Northampton, MA: Edward Elgar Publishing, 2009), pp. 249-71; European Council, 'Council Regulation (EC) No 343/2003 of I8 February 2003 establishing the criteria and mechanisms for determining the Member State responsible for examining an asylum application lodged in one of the Member States by a third-country national', (Council Regulation, European Union, I8 February 2003), <http://eur-lex.europa. eu/LexUriServ/LexUriServ.do?uri=CELEX:32003Ro343:EN:NOT> [accessed 20 December 20I3]. 
regarding the state's new plans to build a CIE (Centro di Identificazione ed Espulsione). ${ }^{8}$ In fact, as the government had begun construction without seeking the proper permits and approvals from other government divisions, it was on an environmental basis that Nicolini and other local activists were able to stop Lampedusa from being transformed from a site of accoglienzato a site of imprisonment and repatriation, successfully changing state practices. A long-time advocate for migrants, Nicolini has significantly altered the conversation about migration on the island by focusing on their rights, humanity, and unreservedly criticizing the state and national politicians for their abuses. ${ }^{9}$ Though local discourse on the island has changed and the mayor no longer defers to politicians like Silvio Berlusconi, the former Prime Minister, who were patently anti-immigrant, the detention centre remains and the state continued to ignore its own rules by delaying transfers and ignoring inhumane conditions at the centre, under the pretence of emergency. Paola La Rosa, an activist, Lampedusa resident, and part of Legambiente, maintains that this discourse of Lampedusa as always in a 'state of emergency' allows for the normalization of inhumane treatment. ${ }^{\text {Io }}$

The rescue of migrants in the Mediterranean has often been overshadowed by tragedies and death: from shipwrecks over sixty miles south of Lampedusa near Libyan waters, to boats that sink in sight of the island. As of October 20I4, 2I,439 migrant deaths have been documented in the Mediterranean since I988, to say nothing of those which had no witness and will always remained uncounted, unnameable, unknown. ${ }^{\text {II }}$

The Catholic Church, from previous Popes to its charity organizations like Caritas, have not only prayed for, but worked to help, migrants in Italy. ${ }^{\mathrm{I} 2} \mathrm{In} 20 \mathrm{I}_{3}$, the newly elected

8 The current centre in Lampedusa is a CSPA, Centro di Soccorso e Prima Accoglienza. Though migrants are meant to stay in these types of primary centres for a maximum of seventy-two hours, this is the exception rather than the rule. Adding a new type of centre, a CIE, whose function would be to house migrants already slated for repatriation for up to eighteen months, would, in effect, have turned Lampedusa into an island prison for migrants and made asylum claims and transfers to the mainland even more difficult.

9 Redazione, 'Lampedusa, filmato choc del centro di accoglienza, Nicolini: “Immagini agghiaccianti”, (I7 December 20I3), AgrigentoNotizie, <http://www.agrigentonotizie.it/cronaca/giusi-nicolini-polemica-filmato-centro-accoglienza-lampedusa.html> [accessed 2I December 20I3].

to S. Gibellini, Paola La Rosa — False informazioni su Lampedusa <http://youtu.be/YVqOE7Dno7M> [accessed I7 December 2013].

II For example, instances like the October 2013 shipwreck sixty-five miles south of Lampedusa, where Libyan authorities shot at the departing boat, overshadow the daily rescues: Stephen Calleja, 'Migrants say they were fired upon leaving Libya', (I3 October 20I3), Washington Times, < http://www.washingtontimes.com/news/20I3/oct/13/migrants-say-they-were-fired-upon-leaving-libya/?page=all> [accessed II June 20I5]. Gabriele Del Grande, 'Fortress Europe: La strage', (20I4), Fortress Europe, < http://fortresseurope.blogspot.com/p/la-strage.html> [accessed II November 20I4].

I2 From social justice research undertaken by Caritas to defending the rights of Muslim immigrants, from priests like Fr. Mussie Zerai whose cell phone number boats in distress know to call to Papal statements for solidarity, the Catholic Church has concretely assisted immigrants and refugees crossing the Mediterranean. Caritas and Migrantes, Dossier Statistico Immigrazione 2012, $22^{\circ}$ Rapporto "Non sono numeri” (Rome, Italy: Centro Studi e Ricerche IDOS, 20I2); Ian Dunn, 'Message of hope ahead of John Paul II's Beatification', (28 April 20II), SCO News, <http://www.sconews.co.uk/news/8668/message-of-hope-ahead-of-john-paul-ii\% $\% 2 \% 80 \% 99$ s-beatification/> [accessed 30 May 20II]; Mitchell Landsberg, 'In Italy, Roman Catholic Church is a leading defender of Muslim immigrants', (I9 July 20I0), LA Times, <http://www.latimes.com/news/nationworld/world/la-fg-catholic-muslim-201007I9,0,609959I.story> [accessed 30 July 20I0]; Antonello Mangano, 'Top Vatican official appeals for solidarity with African boat refugees', (7 April 20II), Catholic News Agency, <http://www.catholicnewsagency. com/news/top-vatican-official-appeals-for-solidarity-with-african-boat-refugees/> [accessed Io April 20II]; Emer McCarthy and Fr. Mussie Zerai, 'Sinai Hostages: A 2Ist Century Tragedy', (I4 October 20II), Vatican Radio, $<$ http://en.radiovaticana.va/storico/20II/Io/I4/sinai_hostages:_a_2Ist_century_tragedy/enI-529050> [accessed 8 February 20I5]. 
Pope Francis continued the Church's concern for migrants by choosing Lampedusa as his first visit outside Rome. The Holy Father was touched by tragic news from Lampedusa such as the Coast Guard's rescue of forty-five migrants adrift in the Canal of Sicily on 2 I June, and a shipwreck on $5_{5}$ June where at least seven drowned while ninety-five were rescued after being found holding onto large tuna cages. ${ }^{\mathrm{I}}{ }^{3}$

Arriving in Lampedusa via plane on 8 July 20I3, Pope Francis was then brought to the dock at Cala Pisana, where he boarded a Coast Guard vessel - the same ones used to rescue migrants - and entered Lampedusa via its port at Molo Favarolo. While at sea, he deposited a wreath of flowers in the water to honour all those migrants who have perished trying to reach the island. Upon disembarking, he greeted a small group of migrants who had been residing at the Lampedusa centre. They read a short letter to him asking for his help and expressing their desire to leave. After this encounter, he drove through the island's town in a borrowed Fiat Jeep to greet the crowds before celebrating Mass.

While the entirety of the Pope's four-hour visit is rife with significance for discourses of migration, in this paper I examine his celebration of the Mass through particular objects. I argue that Pope Francis' use of liturgical objects mobilized particular understandings of migration and the state. More specifically, I argue that these liturgical objects demonstrate how the Pope weaves migrants and their experiences of life and death into a Christian theological narrative so that the objects become material representations of the Catholic social gospel. By seeking to uncover a history of these liturgical objects, I hope to 'make salient what might otherwise remain obscure.'I4 Tracing the histories and meanings of these objects within a larger historical-geopolitical context reveals how they become material representations of political agency; it is via these objects that the realms of religion and state intersect so that the Pope can directly challenge the Italian state and its practices both verbally and visually. His explicit statements in the homily are thus enacted as religious ritual during the Mass through these objects. In criticizing state practices of migration management, Pope Francis thus challenges an essentialized, disembodied understanding of the state. ${ }^{15}$ In the following sections, I use interview data collected in 2013 as well as archival information; I collected relevant documents, news reports, government and legal rulings, public addresses, and videos, and conducted a document analysis. Using these methods, I trace the genealogies of the liturgical objects used at Mass, specifically the altar, chalice, ambo, and ferula to explore how discourses of migration and religion intersect as challenges to Italian state policies.

${ }^{13}$ Redazione Roma Online, 'Papa Francesco a Lampedusa l'8 luglio per incontrare gli immigrati e pregare', (I July 20I3), Corriere della Sera, <http://roma.corriere.it/roma/notizie/cronaca/I3_luglio_I/papa-lampedusa-immigarti-2221936807976.shtml> [accessed I8 December 2013].

${ }^{14}$ Igor Kopytoff, 'The Cultural Biography of Things', in The Social Life of Things: Commodities in Cultural Perspective, ed. by Arjun Appadurai (Cambridge: Cambridge University Press, 1988), pp. 64-94 (67).

${ }^{15}$ For more on how an essentialized, disembodied state is constructed, see Michael T. Taussig, The Magic of the State (New York: Routledge, I997); Timothy Mitchell, 'Society, Economy, and the State Effect', in The Anthropology of the State: A Reader, ed. by Aradhana Sharma and Akhil Gupta (Malden, MA: Blackwell Pub., 2006), pp. I69-85. 


\section{Campo Sportivo: from makeshift migrant shelter to Mass}

In 20II, when refugees fleeing the Arab Spring uprisings were abandoned by the state in Lampedusa, they camped wherever they could. The detention centre for 700 was over-crowded by thousands, and migrants outnumbered the local population. They were given no bathrooms, no showers, no medical care, no shelter. If they were lucky, they received a meal from the detention centre. Locals, activists, and the local Catholic Church community stepped in when the state looked away, distributing blankets and food. Migrants made makeshift tents out of plastic bags, plastic emergency blankets, and whatever else they could find, camping out on the hills surrounding Lampedusa's port. A large number chose the campo sportivo as their campsite. When the detention centre was set on fire in the fall of $20 \mathrm{II}$ in protest by migrants over indefinite detention timelines, it was to this field that migrants fled and slept overnight.

Thousands of migrants had temporarily lived, protested, and suffered in this place. In 20I3, a space in which migrants had languished became the site of Pope Francis' first Mass outside Rome. In celebrating the Eucharist in this place - a memorial of Christ's death and resurrection to new life - we see the parallel transformation of the space from one of suffering, to one of change. For it would be in this place that Pope Francis would begin to change the discourse surrounding migration and Lampedusa in Italy.

\section{Wooden symbols of life and death}

Anthropologist Ann Stoler discusses how colonialism and empire can be studied by looking at ongoing imperial formations, or colonial ruins. ${ }^{16}$ In tracing both the fragile and durable effects of empire, Stoler seeks to remember how colonialism, specifically the longevity of its structures of dominance, is present still today with its ruins still in a process of becoming. ${ }^{17}$ Though focusing on the colonial histories of the objects I examine is beyond the scope of this paper, focusing on items of ruin allows us to ask questions about the politics and social relations surrounding these objects. ${ }^{18}$ Just as Stoler asks the critical question: 'What of those sites of decomposition that fall outside historical interest and preservation, of those places that are not honoured as ruins of empire proper and go by other names?', I look at sites of decomposition, those that are not considered ruins, and instead go by other names — in this case 'trash' — to link their genealogies to present day realities of immigration. ${ }^{\text {I9 }}$

Memory has been a powerful aspect of postcolonial studies. One domination strategy common to varied forms of colonialism is the erasure of a past and common memories. Many postcolonial works seek to recover histories, memories, and trace genealogies of neo-colonialism in order to resist continuing processes of political and intellectual colonization. As such, I seek to trace the histories of the wood from which these liturgical

\footnotetext{
16 Ann Laura Stoler, 'Imperial Debris: Reflections on Ruins and Ruination', Cultural Anthropology, 23.2 (2008), I9I-2I9 (p. I93).

${ }^{17}$ Ibid., p. I93, p. 196.

I8 Ibid., p. I97.

I9 Ibid.
} 
objects are constructed in order to centralize migrant bodies and their experiences within a larger discourse of a religious leader challenging state practices. ${ }^{20}$

In discussing the ruins of migration, I seek to ask questions about the uses and meanings behind these objects, in a sort of salvage memory project. I draw on the work of geographer Caitlin DeSilvey, who employs a method of imaginative recollection to describe and reflect upon the linkages between discarded objects in a Minnesota homestead. ${ }^{21}$ Hirsch and Spitzer have also focused on material remnants of the past, in their case, books from World War II concentration camps, which 'carry memory traces. ${ }^{22}$ Exploring the ways that memories are assembled onto objects can thus reveal the multiple lives, journeys, and geopolitical relations that might otherwise remain obscured.

Migrant stories do not begin or end with the boats they use to cross the Mediterranean. They often leave countries at war or under dictatorial control. Migrants leaving Eritrea, for example, risk being shot if caught leaving the country. ${ }^{23}$ Many are trafficked through the Sahara desert and die there. ${ }^{24}$ Others are kidnapped and held for ransom by traffickers in the Sinai desert where they undergo violence, torture, and death. ${ }^{25}$ Those that make it to northern Libyan cities like Benghazi or Ajdabiya, for example, are often jailed by Libyan police, many of whom had agreements with smugglers to arrest some of the migrants in exchange for allowing others to depart on boats. While in jail with other non-migrant arrestees, migrants described being beaten and raped, being deprived of food and water, and kept in overcrowded conditions. ${ }^{26}$ Dagmawi Yimer, the director

20 For more on how memory erasure and recovery have been central to postcolonial projects and historical recovery as resistance, see M. Jacqui Alexander, Pedagogies of Crossing: Meditations on Feminism, Sexual Politics, Memory, and the Sacred (Durham, NC: Duke University Press, 2005); Derek Gregory, The Colonial Present: Afghanistan, Palestine, and Iraq (Malden, MA: Blackwell Pub., 2004); Albert Memmi, The Colonizer and the Colonized (New York: Orion Press, 1965); Andrea L. Smith, Colonial Memory and Postcolonial Europe: Maltese Settlers in Algeria and France (Bloomington: Indiana University Press, 2006); K. E. Supriya, Remembering Empire: Power, Memory, \& Place in Postcolonial India (New York: P. Lang, 2004). A. Taylor, “The Sun Always Shines in Perth”: A PostColonial Geography of Identity, Memory and Place', Australian Geographical Studies, 38.I (2000): 27-35; Hershini Bhana Young, Haunting Capital: Memory, Text and The Black Diasporic Body (Lebanon, NH: UPNE, 2006).

2I Caitlin DeSilvey, 'Salvage Memory: Constellating Material Histories on a Hardscrabble Homestead', Cultural Geographies, I4.3 (2007): 40I-24.

22 Marianne Hirsch and Leo Spitzer, 'Testimonial Objects: Memory, Gender and Transmission', in Diaspora and Memory: Figures of Displacement in Contemporary Literature, Arts and Politics, ed. by Marie-Aude Baronian, Stephan Besser, and Yolande Jansen (Amsterdam: Rodopi, 2007), pp. I37-I64 (I39).

23 According to Amnesty International, "Per coloro che venivano colti nel tentativo di varcare il confine con l'Etiopia è rimasta in vigore la prassi di “sparare per uccidere”.' Joseph Zarlingo, 'In fuga dall'Eritrea, dove il regime spara su chi fugge e tartassa chi rimane', (3 October 2013), Il Fatto Quotidiano, < http://www.ilfattoquotidiano.it/2013/Io/o3/in-fuga-dalleritrea-dove-regime-spara-su-chi-fugge-e-tartassa-chirimane/73I626/> [accessed 2I December 20I3].

24 A cell phone video captured by someone travelling from Libya to Niger documented the fate of migrants who die in the Sahara, expelled on foot in 'la rotta degli schiavi': 'Cosi finiscono gli uomini e le donne che non sbarcano più a Lampedusa. Bloccati in Libia dall'accordo Roma-Tripoli e riconsegnati al deserto.' Fabrizio Gatti, 'Morire nel deserto' (I4 January 20Io), l'Espresso, < http://espresso.repubblica.it/internazionale/20Io/oI/I4/news/morire-nel-deserto-I.I7943> [accessed 28 August 20I0].

25 Those trafficked and ransomed in the Sinai contacted Fr. Zerai in Rome, who documented their torture in a Radio Vaticana radio broadcast. McCarthy and Zerai, 'Sinai Hostages: A 2Ist Century Tragedy'.

${ }^{26}$ While this is the case for most boats leaving from Libya, Del Grande documents some cases of Tunisians purchasing their own boats or having them specially made before departing to ensure a safer voyage: Il mare di mezzo, esp. p. I2, p. I7. 
of the film Come un nomo sulla terra, stated, 'Although you are being sold like a slave, you are happy to leave that place.' Unfortunately for many migrants, and for all those in Yimer's film, they undertook the journey and suffered the same violence multiple times over. For example, John was arrested seven times and sold five times before eventually making it to Italy. After being sold to Sudanese traffickers, they are again brought to northern cities, where they are caught by police, jailed, and brought back to prisons like Kufrah. For most, it takes more than one year, and often two, to make it from Sudan or sub-Saharan Africa to a boat that will leave for Italy. If their boat is subject to respingimento, or pushback, they will be put back into the circuitous system, or worse. As Del Grande documents, in Tunisia, pushed-back migrants are placed in secret jails for years with no contact with family and often presumed dead. ${ }^{27}$

Once migrants are able to make the passage by boat, they must board whatever vessel is presented them. According to UNHCR workers, some migrants are forced to leave even when they do not want to. ${ }^{28}$ Traffickers often provide boats in very poor conditions that are no longer considered seaworthy by fishermen and others. While some of these boats capsize or sink due to overcrowding, age, and poor construction, many make it to Italian national waters and the shores of Lampedusa. Boats in distress that are rescued by Italian authorities have one of three ends: I) if they are sinking, once migrants are rescued they are left to sink 2) boats still in good condition are towed to Lampedusa 3) if migrants are transferred to Italian rescue vessels, boats are left to drift or sink at sea. Boats towed to Lampedusa are then transferred inland to the 'boat cemetery'. Here, boats are haphazardly piled on one another until there is no more space. At this point, a special machine is brought to the island and breaks them down. A pile over three stories high of fading blue wood lies in the background of the more recent, still intact boats. Despite their sometimes poor quality, they are brightly painted in red, blues, and yellows, feature Arabic script, and handprints in paint. At certain points under the previous mayor, the boats have mysteriously caught fire (later ruled arson) ostensibly to eliminate the need for proper clean-up while still keeping the funds allocated for the job. ${ }^{29}$ What information do these old pieces of wood consigned to the trash reveal?

For some, like local woodworker/carpenter and artist Francesco Tuccio, these boats contain memories, suffering, religion, and new life. Since 2009, Tuccio has used wood he has reclaimed from boats in the boat cemetery, or pieces that have washed up on shore, to create religious art. He began in 2009 creating crosses from the ruins of migrant boats:

Ho cominciato a fare la prima croce, come forma di protesta, per fare conoscere un po' a tutti la sofferenza tramite questo legno abbandonato, per fare portare alla vita, no? Poi io con un pezzo di legno buttato porto alla vita qualcosa d'importante che poi rappresenta anche la vita di loro, una vita un po' calpestata, di sofferenza, che poi la croce porta la sofferenza ma porta anche la rinascita. ${ }^{3 \circ}$

28 Marco Bariletti, Le strane coincidenze negli arrivi dei barconi. (I7 May 20II; TGıonline.) < http://youtu.be/no-t3t8lZ 4 c $>$ [accessed I3 November 20I4].

29 Marco Bariletti, Lampedusa, il business dei barconi, pt.2. (I8 February 20II; TGIonline.) < http://youtu.be/kZRA3oBD_Fk> [accessed I3 November 20I4].

30 These and all further interview data from Tuccio refers to 'Francesco Tuccio interview, I7 November 20I3'. 
He does not sell his work, but does it out of love, inspiration, and by request. Priests have asked for crosses made from the wood of migrant boats from all over Italy and one was gifted by the local priests in 20 I I to Pope Benedict when they visited Rome. For Tuccio, the creation of these crosses comes from a moment of religious inspiration. He directly links the suffering of Christ on the cross to the suffering endured by migrants who reach Lampedusa. He recognizes that the suffering is not just in the crossing, but in a life of suffering, one that begins with the need to migrate and the multiple forms of violence endured throughout the entire journey, and even upon their arrival in Italy. Here we also see how the life of migrants, as represented by discarded wood, is woven into the narrative of Christian salvation. Though the boats they travel in are full of suffering - overcrowding, poor condition, bad weather, lack of food and water, death and drowning - they can at moments be a place for new life. Not just the chance for a new life in Italy or the EU, but the literal birth of new life. On 26 March 20I I, a female migrant gave birth to a child while the boat carrying her was adrift at sea. Upon being rescued by the Italian military, the woman was brought to Lampedusa and then flown via helicopter to Palermo. Just a few weeks later, on I9 April 20II, a woman on board a boat with 760 other migrants landed in Lampedusa in the early stages of labour. She gave birth to a child on Lampedusa, the first child born on the island in over thirty years. ${ }^{3 \mathrm{I}}$ These children, though born on Italian soil, are not granted citizenship, which in Italy is based on parental bloodline. Both these women were from Eritrea, a former Italian colony, which has been experiencing war intermittently since decolonization. These examples show how migrant boats, or 'trash', become the sites of reproduction, life, death, and the reification of denying citizenship to formerly colonized individuals. In transforming parts of these boats into crosses, Tuccio reveals the interconnections between their materiality, religion, and migration. For Tuccio, his transformation of the wood into crosses is a way to let everyone know 'la sofferenza di questi nostri fratelli'.

It is fitting therefore, that the stories and bodies of these migrant men and women, whom Tuccio calls his fellow brothers and sisters, all part of the same body of Christ, be incorporated into the Mass celebrated by Pope Francis. Tuccio worked for the five days before Pope Francis' unexpected visit to create the various objects used at the Mass. The papal ferula, or pastoral staff, was made from wood Tuccio recovered from the boat cemetery (see Figure 2). Using a former migrant boat's stem, he made a cross of red and blue wood, carving two fish and five loaves into it, a reference to the Gospel miracle of the loaves and fishes, symbol of the Eucharist. Thus, the hunger migrants experience on their journeys, the violence they suffer, are assembled onto one piece of wood. Discarded then repurposed to deliberately mark migrants and their suffering as part of a larger suffering that must be experienced by the larger body of Christ, the Church itself and all

\footnotetext{
3I The island of Lampedusa does not have a hospital, just a small clinic. For this reason, since childbirth became medicalized, Lampedusan women have travelled to Palermo a few weeks before their due dates and give birth in the hospital there. Women who go into labour early while still on Lampedusa are flown via medical helicopter to Palermo - a 45 minute flight - and give birth there. For more details on the birth of these children on/near Lampedusa, see: ANSA, 'La Storia: Ecco Gifty, la bimba nata ieri a Lampedusa — Photostory Primopiano' (20 April 20II), < http://www.ansa.it/web/notizie/photostory/primopiano/20II/04/20/visualizza_new.html_899573447.html> [accessed 2I April 20II]; La Repubblica, 'L'arrivo del piccolo nato sul barco - Video' (26 March 20II), < http://video.repubblica.it/dossier/emergenza-lampedusa-20Io/l-arrivo-del-piccolo-nato-sul-barcone/64973/63549> [accessed 7 April 20II].
} 
its members. The ferula became a reminder that the suffering of migrants is the suffering of all, and therefore, a suffering we must all seek to end.

Along with the small group that greeted and spoke with the Pope at his arrival at the port, migrants were also in attendance at the Mass. Two Catholic migrants participated directly, bringing up the gifts/offering to the altar before the liturgy of the Eucharist. Unlike other famous visits to the island, migrants are not made to stay in the detention centre, a sanitized few to perhaps be seen..$^{32}$ They are involved directly; the spotlight is on them. Politicians and the famous were specifically and publically invited not to attend. ${ }^{33}$ In selecting believing, Catholic migrants to take part in one of the opportunities for the laity to participate in the celebration of Mass, migrants are again centralized. In this act, they are representatives of the faithful; not just the migrant community, but of the Body of Christ within this congregation. ${ }^{34}$ This act, then, becomes more than a simple religious ritual, but is a spiritual-political claim proclaiming the human dignity of those usually considered Other. While immigrants are included as citizens of the Church during Mass, they are simultaneously excluded from citizenship within the Italian state. In a way, therefore, their inclusion here politicizes a seemingly apolitical aspect of a religious event.

Tuccio also constructed the lectern from wood reclaimed from the boat cemetery. Though he does not know the specific dates and voyages this wood made, he does know their geographical origin. The two external parts were created with the rudders of two Tunisian boats while the centre piece is a rudder from a Libyan boat. The wheel decorating the front is also from a Libyan boat (see Figure 3). Here is a material representation of the two diverse migrant flows to Lampedusa, united as one. He specifically chose three rudders as the main structure to represent the trinity. It is significant, then, which readings were selected to be proclaimed from this lectern, which symbolically reminds the viewer of God's triune nature.

The readings for this special Mass — Genesis 4, Psalm 5I, John I 5:I2, Matthew 2 come from the penitential selections, also signified by the violet worn by the Pope and the other priests. ${ }^{35}$ This selection of colour and readings is important. In celebrating a

32 For more on the visits of famous people like Angelina Jolie or then Prime Minister, Silvio Berlusconi, see Barbara Giangravè, 'La visita a Lampedusa era di Gutierrez, non della Jolie', (20 June 20II), <http://www.siciliaonline. it/speciali/speciale-lampedusa/36389-la-visita-di-ieri-a-lampedusa-era-di-gutierrez-non-della-jolie $>$ [accessed 2 I June 20II]; 'Berlusconi show a Lampedusa; "Entro 48-60 ore isola liberata”', (30 March 20II), La Repubblica, $<$ http://www.repubblica.it/politica/20I I/03/30/dirette/berlusconi_arriva_a_lampedusa_sono_poveri_cristi_aiutiamoli-I 4250480/> [accessed I7 February 20I2]; Giacomo Sferlazzo, 'C’è una parte di Lampedusa che qualcuno non vuole ascoltare’, (23 September 20II), Giovani Lampedusa, <http://www.giovanilampedusa.it/blog/440-ce-unaparte-di-lampedusa-che-qualcuno-non-vuole-ascoltare.html > [accessed 25 September 20II].

33 Civil, military, and religious authorities, as relayed in the official Vatican letter to Mayor Nicolini, 'devono sentirsi dispensate dalla presenza non per mancanza di rispetto ma per conservare lo stile privato della visita.' Alessandra Ziniti, 'Il Papa lunedì a Lampedusa “Ma le autorità restino a casa”', (2 July 20I3), La Repubblica, < http://ricerca.repubblica.it/repubblica/archivio/repubblica/2013/o7/o2/il-papa-lunedi-lampedusa-ma-le-autorita. html> [accessed 2I December 20I3].

34 United States Conference of Catholic Bishops, 'The Preparation of the Gifts', General Instruction of the Roman Missal (Washington, DC: USCCB, 20I0), <http://www.usccb.org/prayer-and-worship/the-mass/general-instruction-of-the-roman-missal/girm-chapter-2.cfm> [accessed 2I December 2013].

35 United States Conference of Catholic Bishops, 'Sacred Vestments', General Instruction of the Roman Missal (Washington, DC: USCCB, 20I0), <http:://www.usccb.org/prayer-and-worship/the-mass/general-instruction-of-the-roman-missal/girm-chapter-2.cfm> [accessed 2I December 20I3]. 


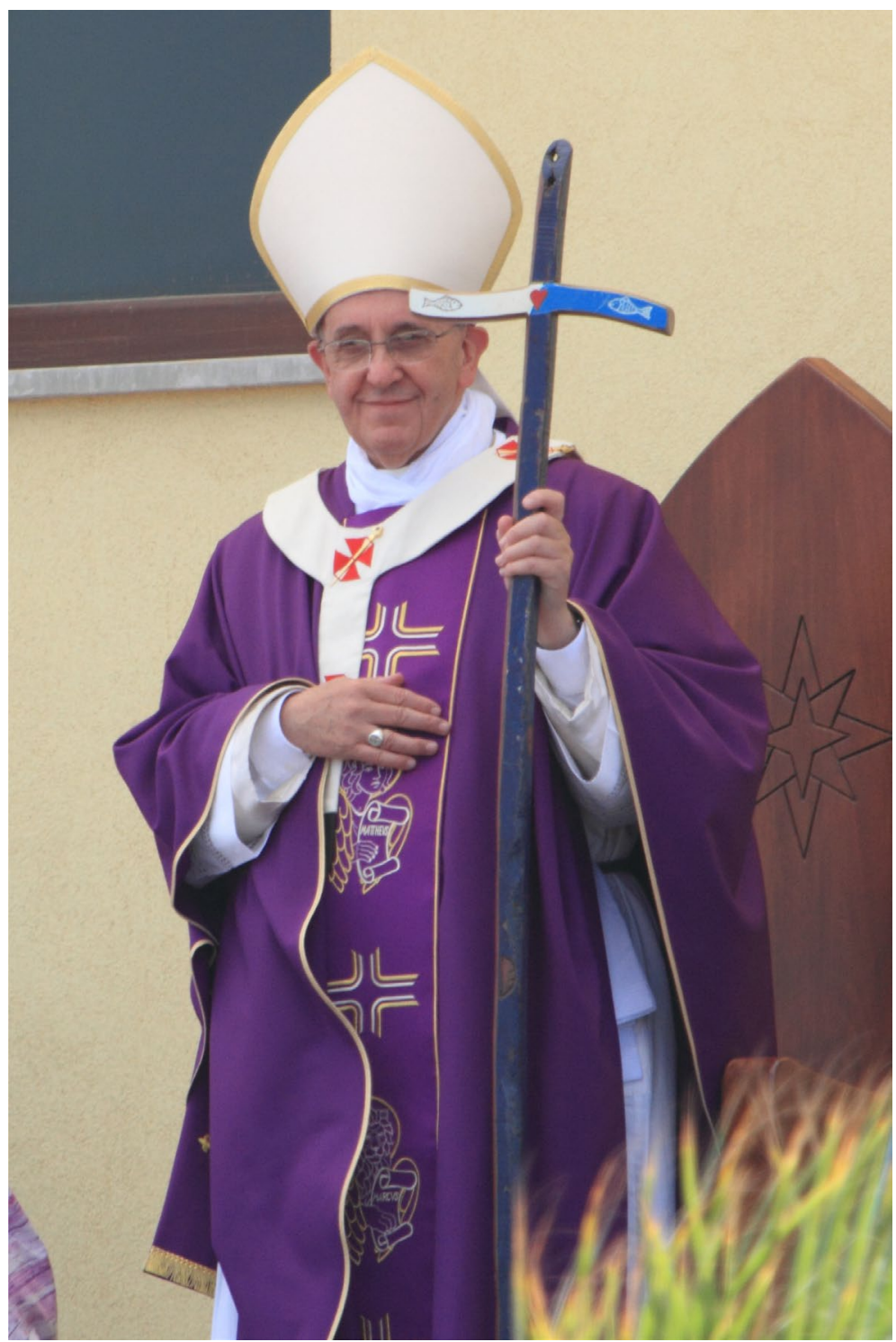

FIGURE 2 Pope Francis with ferula made from former migrant boats by local woodworker, Francesco Tuccio. Photograph taken 9 July 2013, by Pietro Tuccio.

penitential Mass in memory of those who have died trying to migrate, the Pope is literally having the Church, as in the responsorial psalm, claim this sin as their own and ask forgiveness for it. The Word of the Lord pro-claimed from a lectern, created by a Catholic Lampedusan with boats from Tunisia and Libya, weaves together many histories. Here the instructions of the Lord - care for one's brother, loving others self-sacrificially as Christ loves us, recognizing and asking forgiveness for our sins, and recognizing the role of the state in the deaths of innocents - are materialized onto the bodies of these migrants. Not simply the migrants who lost their lives in the most recent tragedy, but 


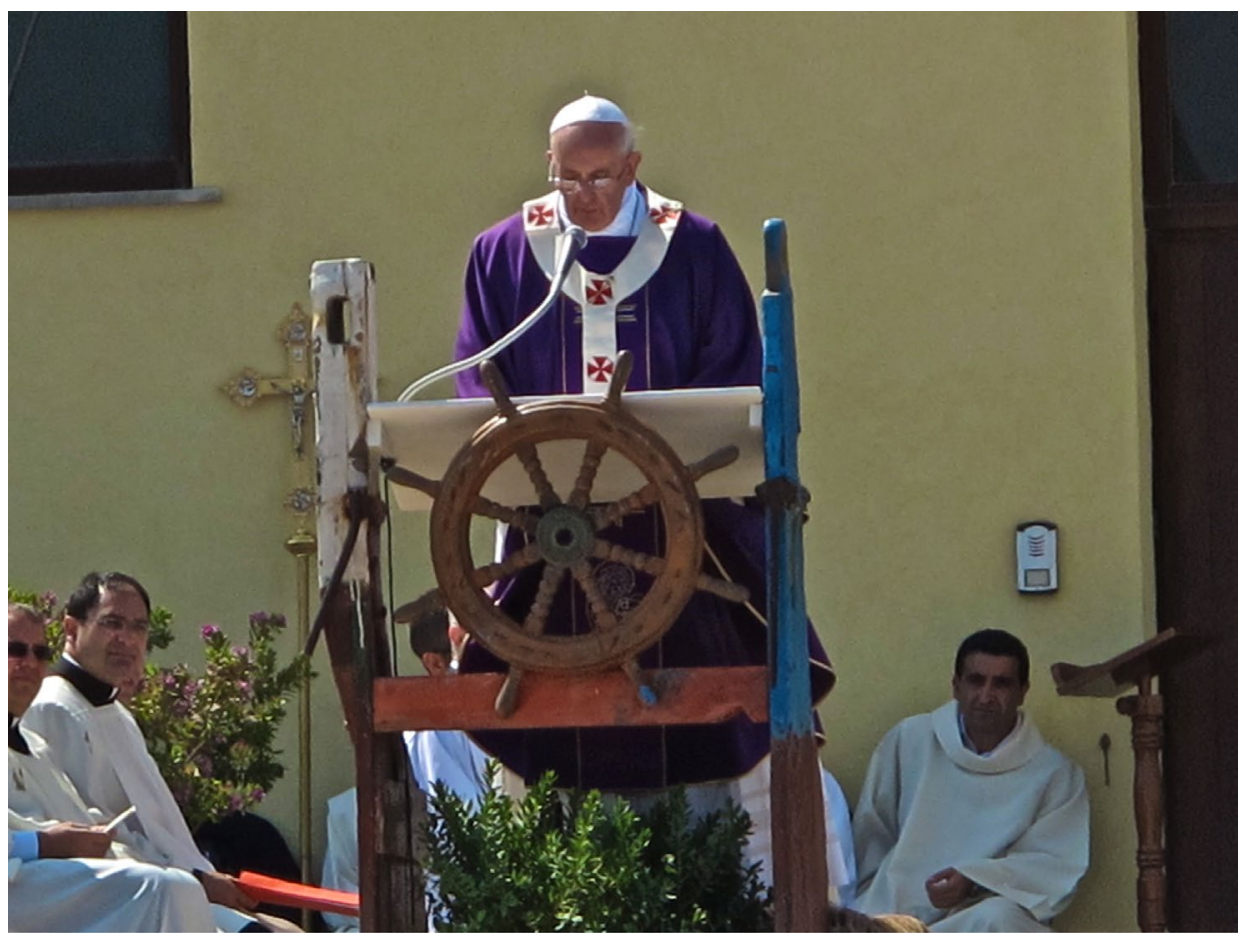

FIGURE 3 Pope Francis delivers his homily from a lectern created from wooden migrant boats. Photograph taken 8 July 2013, by Fabio Giovanetti for Archivio Storico Lampedusa.

in all the migrants who have survived, who have died, who will survive, and who will die. There is no distinction as to the religious beliefs of migrants; many are Christian or Muslim. During the homily, Pope Francis offers solidarity to Muslim immigrants who will begin Ramadan that evening. Migrants from many faiths and nations join in Libya or Tunisia to depart for the EU, yet our concern for them should not be based on their religious profession, but based on their humanity as children of God. In a seemingly apolitical event, a space for politics through the language of religion emerged.

The meanings that these objects' histories visually point to are then made tangible by the Pope's homily. He begins with immigrants and the boats: 'Immigrati morti in mare, da quelle barche che invece di essere una via di speranza sono state una via di morte. ${ }^{36}$ Here Pope Francis verbally links the boats and their histories with the lives and deaths of migrants, as well as with the objects created from them used throughout the Mass. Further, by later linking migrants with the 'brother' whom the Lord asks all of us to care for, he places migrants not at the margins, but at the centre of the Catholic social gospel. He reminds us that the present day marginalization of migrants, a site of structural and

${ }^{6}$ Pope Francis, 'Visita a Lampedusa: Omelia del Santo Padre Francesco', (8 July 2013), Libreria Editrice Vaticana, < http://w2.vatican.va/content/francesco/it/homilies/20I3/documents/papa-francesco_20130708_omelia-lampedusa. html> [accessed I9 December 20I3]. 
symbolic violence, has become so normalized, that individual responsibility for migrant deaths is impossible: 'l'altro che non è più il fratello da amare, ma semplicemente l'altro che disturba la mia vita, il mio benessere'. Thus, he calls all, especially 'coloro che con le loro decisioni a livello mondiale hanno creato situazioni che conducono a questi drammi,' to responsibility. ${ }^{37}$

Anche oggi questa domanda emerge con forza: Chi è il responsabile del sangue di questi fratelli e sorelle? Nessuno! Tutti noi rispondiamo così: non sono io, io non c'entro, saranno altri, non certo io. Ma Dio chiede a ciascuno di noi: 'Dov'è il sangue del tuo fratello che grida fino a me?’. Oggi nessuno nel mondo si sente responsabile di questo; abbiamo perso il senso della responsabilità fraterna..$^{8}$

The two main readings, Genesis and Matthew, are about murder. ${ }^{39}$ Their selection indicates that the deaths of migrants are not without individual culpability. And here in the homily, the Pope states that we cannot simply continue to claim that no one is to blame for their deaths. In fact, to do so, is to participate in the 'globalizzazione dell'indifferenza', which is in part responsible for their deaths. ${ }^{40}$

It is precisely in his language of indifference where Pope Francis' most direct challenge to current state practices of migration management can be observed.

In questo mondo della globalizzazione siamo caduti nella globalizzazione dell'indifferenza.

Ci siamo abituati alla sofferenza dell'altro, non ci riguarda, non ci interessa, non è affare nostro! [...] Erode ha seminato morte per difendere il proprio benessere, la propria bolla di sapone. E questo continua a ripetersi [...] Domandiamo al Signore che cancelli ciò che di Erode è rimasto anche nel nostro cuore; domandiamo al Signore la grazia di piangere sulla nostra indifferenza, di piangere sulla crudeltà che c'è nel mondo, in noi, anche in coloro che nell'anonimato prendono decisioni socio-economiche che aprono la strada ai drammi come questo. ${ }^{\mathrm{I}}$

In invoking Herod from the Gospel reading, who caused the slaughter of innocent children because he wanted to retain his sovereign power, we see a parallel to the Italian state. States in general function in such a way as to maintain their own power and existence. ${ }^{42}$

37 For more on how a Catholic theology of migration understands human dignity, borders, and the right to migrate through the theological principles undergirding Catholic social teaching, see: Gioacchino Campese, 'The Irruption of Migrants: Theology Of Migration in the 2Ist Century', Theological Studies, 73.I (20I2): 3-32; Drew Christiansen, 'Movement, Asylum, Borders: Christian Perspectives', International Migration Review, 30.I (I996): 7-I7; Daniel G. Groody, C.S.C., 'Crossing the Divide: Foundations of a Theology of Migration and Refugees', Theological Studies, 70.3 (2009): 638-67; Daniel G. Groody and Gioacchino Campese, A Promised Land, A Perilous Journey: Theological Perspectives on Migration (Notre Dame, Ind.: University of Notre Dame Press, 2008).

${ }_{38}$ Pope Francis, 'Visita a Lampedusa: Omelia del Santo Padre Francesco'.

39 Briefly, the Genesis reading recounts the first fratricide, Cain's murder of Abel; while Matthew describes Herod's order to slaughter the male children of Bethlehem.

4. Pope Francis, 'Visita a Lampedusa: Omelia del Santo Padre Francesco'.

${ }_{4 \mathrm{I}}$ Ibid.

$4^{2}$ For more, see Michel Foucault, 'Governmentality', in Citizenship: Critical Concepts, ed. by Bryan S. Turner and Peter Hamilton (New York: Routledge, I994), and his discussion of Machiavelli and de La Perrière; Begoña Aretxaga, 'Maddening States', Annual Review of Anthropology, 32.I (2003), 393-4Io. 
The Italian state has continuously practiced respingimento, which human rights groups and the European Court deem illegal. ${ }^{43}$ No support is given to asylum seekers and the European Union's Dublin II Regulation restricts migrants' mobilities and agency. ${ }^{44}$ The Italian state, in its current political configuration, promises citizenship only to dead migrants; if they die en masse and under enough media attention. ${ }^{45}$ Italian politicians ignore Lampedusa and migrants, focusing on them only when it is politically expedient or necessary. ${ }^{46}$ Prime Minister Enrico Letta and Deputy Prime Minister Angelino Alfano promise to mourn the deaths of migrants from one of the most recent shipwrecks, 3 October 20I3; and then quickly forget. They use Lampedusa for their political spectacles and quickly return to Rome to pass and enforce legislation that criminalizes migrants and militarizes the Mediterranean, in complete disregard for the humanity of migrants. ${ }^{47}$

The state which Pope Francis challenges is one that claims to be Janus-faced, at once too weak to make changes and too strong to want to make them. It is the essentialized, disembodied state made up of anonymous institutions.$^{48}$ Instead, Pope Francis calls out the state for what it is, an assemblage of individuals. ${ }^{49}$ Individuals who make decisions that sometimes lead to the deaths of others: 'coloro che nell'anonimato prendono decisioni socio-economiche che aprono la strada ai drammi come questo. ${ }_{50}$

With this homily, Pope Francis challenges the state, the individuals who work for it and represent it, and all individuals, to ask forgiveness for their sins of indifference and to repent and change.

43 European Court of Human Rights, 'Case of Hirsi Jamaa and Others v. Italy; (Application no. 27765/o9); Judgment', (Strasbourg, Austria 23 February 20I2); UNHCR, 'Stop ai respingimenti in Libia', (I5 May 2009), MeltingPot.org, < http://www.meltingpot.org/Unhcr-Stop-ai-respingimenti-in-Libia.html\#.VXoZb_n2CoM> [accessed II June 20I5].

44 Broeders, 'Tracing, Identifying and Sorting'; European Council, 'Council Regulation (EC) No $343 / 2003$ of I8 February 2003 establishing the criteria and mechanisms for determining the Member State responsible for examining an asylum application lodged in one of the Member States by a third-country national'; Fulvio Vassallo Paleologo, 'L'Italia non è un paese sicuro per richiedenti asilo', (7 October 20I3), Magistratura Democratica, $<$ http://www.magistraturademocratica.it/mdem/qg/articolo.php?id=220> [accessed 7 October 20I3]

45 Pablo Ordaz, 'Solo los muertos pueden quedarse', (8 October 2013), El País, <http://internacional.elpais.com/ internacional/20I3/ro/o5/actualidad/I380999528_6I3934.html> [accessed I8 November 20I3].

$4^{6}$ La Repubblica, 'Berlusconi show a Lampedusa; "Entro 48-60 ore isola liberata”'; Enrico Montalbano, 'Superstiti e bare: Il Tradimentodell'Europa (Survivors and Caskets: TheBetrayalofEurope)', (20November 2013), The Postcolonialist, < http://postcolonialist.com/featured/superstiti-e-bare-il-tradimento-delleuropa-survivors-and-caskets-the-betrayalof-europe/> [accessed 20 December 20I3].

47 Famiglia Cristiana, 'Legge Bossi-Fini, un vero fallimento', (I2 May 2013), <http://www.famigliacristiana.it/articolo/cie-e-bossi-fini-fallimentari.aspx> [accessed I8 November 20I3]; Giuseppe Pipitone, 'Naufragio Lampedusa, per le vittime tumulazioni anonime e nessun funerale', (I6 October 20I3), Il Fatto Quotidiano, <http://www.ilfattoquotidiano.it/20I3/Io/I6/naufragio-lampedusa-per-vittime-tumulazioni-anonime-e-nessun-funerale/746226/> [accessed I6 October 2013].

$4^{8}$ Colin Gordon, 'Governmental Rationality', in The Foucault Effect, ed. by Graham Burchell, Colin Gordon, and Peter Miller (Chicago: University of Chicago Press, I99I), pp. 626-46 (29); Derek Gregory, 'Vanishing Points', in Violent Geographies: Fear, Terror, and Political Violence, ed. by Derek Gregory and Allan Richard Pred (New York: Routledge, 2007), pp. 205-36; Diane M. Nelson, Reckoning: The Ends Of War In Guatemala, (Durham: Duke University Press, 2009), pp. 208-4I.

49 For example, Judith Butler, Precarious Life: The Powers of Mourning and Violence (London: Verso, 2006), (pp. 5I-52), and esp. discussion of petty sovereigns (p. 56).

50 Pope Francis, 'Visita a Lampedusa: Omelia del Santo Padre Francesco. 
Signore, in questa Liturgia, che è una Liturgia di penitenza, chiediamo perdono per l'indifferenza verso tanti fratelli e sorelle, ti chiediamo Padre perdono per chi si è accomodato e si è chiuso nel proprio benessere che porta all'anestesia del cuore, ti chiediamo perdono per coloro che con le loro decisioni a livello mondiale hanno creato situazioni che conducono a questi drammi. Perdono Signore! ${ }^{51}$

And while he challenges the state to conform to the Catholic social gospel, he does not absolve all others from their responsibility and cooperation in the tragedies of migration through their indifference: “Dov'è il tuo fratello?", la voce del suo sangue grida fino a me, dice Dio. Questa non è una domanda rivolta ad altri, è una domanda rivolta a me, a te, a ciascuno di noi. ${ }^{52}$ Here we see the verbal confirmation of what the Mass and its liturgical objects represent. Pope Francis' visit to Lampedusa, to what some consider the 'end of the world,' 53 is meant to challenge individual actions by calling for religious reflection: 'Questa mattina, alla luce della Parola di Dio che abbiamo ascoltato, vorrei proporre alcune parole che soprattutto provochino la coscienza di tutti, spingano a riflettere e a cambiare concretamente certi atteggiamenti. ${ }_{54}$ That his words, which immediately flooded Twitter and Catholic news outlets throughout the world, were proclaimed from a lectern made of discarded migrants boats, next to an altar composed of a single boat, demonstrate the significance of the visual and the verbal intersecting. These objects become the co-text and context for his homily. Objects that are normally discarded (boats), together with people the state wants to ignore and hide in detention (migrants), are joined to change the discourse and challenge current state practices, a challenge Pope Francis has continued to emphasize in his papacy. ${ }^{55} \mathrm{~A}$ space was created where through religious belief and discourse, the national discourse could be

$5^{1}$ Ibid.

52 Ibid.

53 One local resident linked Lampedusa's position as the end of Europe, the end of one world in a way, to Pope Francis' own declaration upon his election that he came from the end of the world, referencing Argentina and his own migrant background (Resident Interview, 29 November 20I3). The archbishop of Agrigento, Mons. Montenegro, stated, 'It is meaningful that Pope Francis made his first trip to Lampedusa, thus putting into practice what he asked: to go to the end of the world, to the peripheries and the poor.' See Andrea Gagliarducci, 'Pope's island visit carried light to end of world', (I5 July 20I3), Catholic News Agency, < http://www.catholicnewsagency.com/news/popes-island-visit-carried-light-to-end-of-world/> [accessed I9 December 20I3].

54 Pope Francis, 'Visita a Lampedusa: Omelia del Santo Padre Francesco'.

55 From inviting a Lampedusan family to Rome and decrying the onerous paperwork of asylum applications to buying telephone cards for immigrants in the Lampedusa centre, the Pope has taken concrete actions and continued to critique state practices. Quotidiano Nazionale, 'Papa Francesco compra le schede telefoniche per i migranti di Lampedusa; E chiede aiuto a Caritas e Save the Children per i bambini naufraghi', (II October 20I3), Quotidiano.net, < http://qn.quotidiano.net/cronaca/20I3/Io/II/9640I6-papa-francesco-compra-schede-telefoniche-migranti.shtml> [accessed 2I December 20I3]; Vatican TV, Pope's General Audience - Udienza Generale del Papa - 2013-10-09. (9 October 2013; Vatican City: Vatican TV.) < http://www.youtube.com/watch?v=FYHAsTdriXY> [accessed 2I December 20I3]; Pope's meeting with families - Incontro del Papa con le Famiglie 2013-10-27. (26 October 20I3; Vatican City: Vatican TV.) < http://www.youtube.com/watch?v=YI84FerFMJ4 > (accessed December 2I, 20I3). This is also evidenced by his recent naming of Agrigento's Archbishop Francesco Montenegro as Cardinal in January 20I 5. Cardinal Montenegro concelebrated Mass with Pope Francis in Lampedusa and has worked for immigrant rights during his episcopacy. See La Repubblica, 'Il Papa nomina cardinale Montenegro, arcivescovo di Agrigento', (4 January 20I5), < http://palermo.repubblica.it/cronaca/2015/or/o4/news/il_papa_nomina_cardinale_montenegro_arcivescovo_di_ agrigento-I04263077/> [accessed I9 January 2015]. 
transformed, like the boats that became crosses. In fact, one Lampedusa activist happily recalls that the discourse did change following the Pope's visit. Starting that day as she read and watched Italian media, she noticed that many Italian news outlets had stopped using the word clandestini to describe migrants in favour of others like profughi. ${ }^{6}$ In terms of state reactions, not everyone embraced the Pope's message. Politicians whose positions have been historically anti-immigrant, such as Fabrizio Cicchitto of the conservative PDL party, critiqued the Pope's Lampedusa message and sought to explain away and correct his focus on individual responsibility, claiming that religious homilies and state practices should remain separate. Erminio Boso of the far-right Lega Nord party, for example, stated: 'Sono contento se affonda un barcone [...] Non me ne frega niente di quello che ha fatto il Papa.' 57 Others, however, like Minister of Integration Cécile Kyenge, publically agreed with Pope Francis, saying that his concern for migrants is where her politics begin as she seeks to translate his words into practice.

\section{From the blood of migrants to the blood of Christ}

During one of the final parts of the Mass, the liturgy of the Eucharist, the altar, is highlighted. Upon this altar, the bread and wine offered up by the migrants will be transub-stantiated into the body and blood of Christ. Once a small Tunisian boat migrants used to reach Lampedusa, the boat was transformed into a sacred, liturgical surface (see Figure 4). The item for whom the biography is most complete, the chalice, became a central part of the celebration of Mass.

It is approximately 4 a.m., early morning of 8 May, 20II..$^{8}$ The sea is rough and the waves and the wind fight to be heard over one another. Pitch black, the only lights, the few from the rescuers. People are screaming, in Italian, in Arabic, in English, in too many languages. Waves crash into the rough rocks at Cavallo Bianco, just outside the port of Lampedusa. The large wooden boat, at least two levels high, tips back and forth with the waves. Rescuers from the Guardia di Finanza (GdF) and the Coast Guard try to dock the boat to the rocks, tying rope around jagged edges not meant to stabilize a boat this size, with this many people, in this terrible weather. Giant splashes into the sea. Migrants are jumping in, scared the boat will tip and capsize. A mother throws her child to a rescuer on the rocks; he catches it with relief. Coast Guard officials in scuba gear move around the water, searching for fallen migrants, trying to guide people to shore. Migrants climb over the rocks to safety, the thin gold emergency blankets crinkling with the wind.

${ }_{56}$ Activist Interview, 29 November 2013. A Lexis-Nexis Academic search of all Italian news sources for the words (and their derivatives) clandestini and profughi mirrors her observation. Of news sources who used either of these words, only 2.86 per cent of them used profughi in the month before the Pope's visit (97.I3 per cent using clandestini), while this number climbed to I6.2 I per cent the day of his visit. His visit did not eliminate the use of clandestini, however, as that day's news sources still used it over profughi 83.79 per cent of the time.

57 'Migranti, Cicchitto corregge il Papa. E Boso: "Spero affondi un barcone”', (9 July 2013), La Repubblica < http://www.repubblica.it/politica/20I3/o7/og/news/papa_a_lampedusa_la_riflessione_di_cicchitto_un_conto_ predicare_un_altro_governare-6266480I/> [accessed 2I December 2013].

58 Guardia di Finanza, Lampedusa, barcone contro gli scogli: panico tra i migranti. (8 May 20II) La Repubblica $<$ http://video.repubblica.it/dossier/emergenza-lampedusa-2oro/lampedusa-barcone-contro-gli-scogli-panico-tra-imigranti/67855/66315> [accessed 20 December 2013]. 


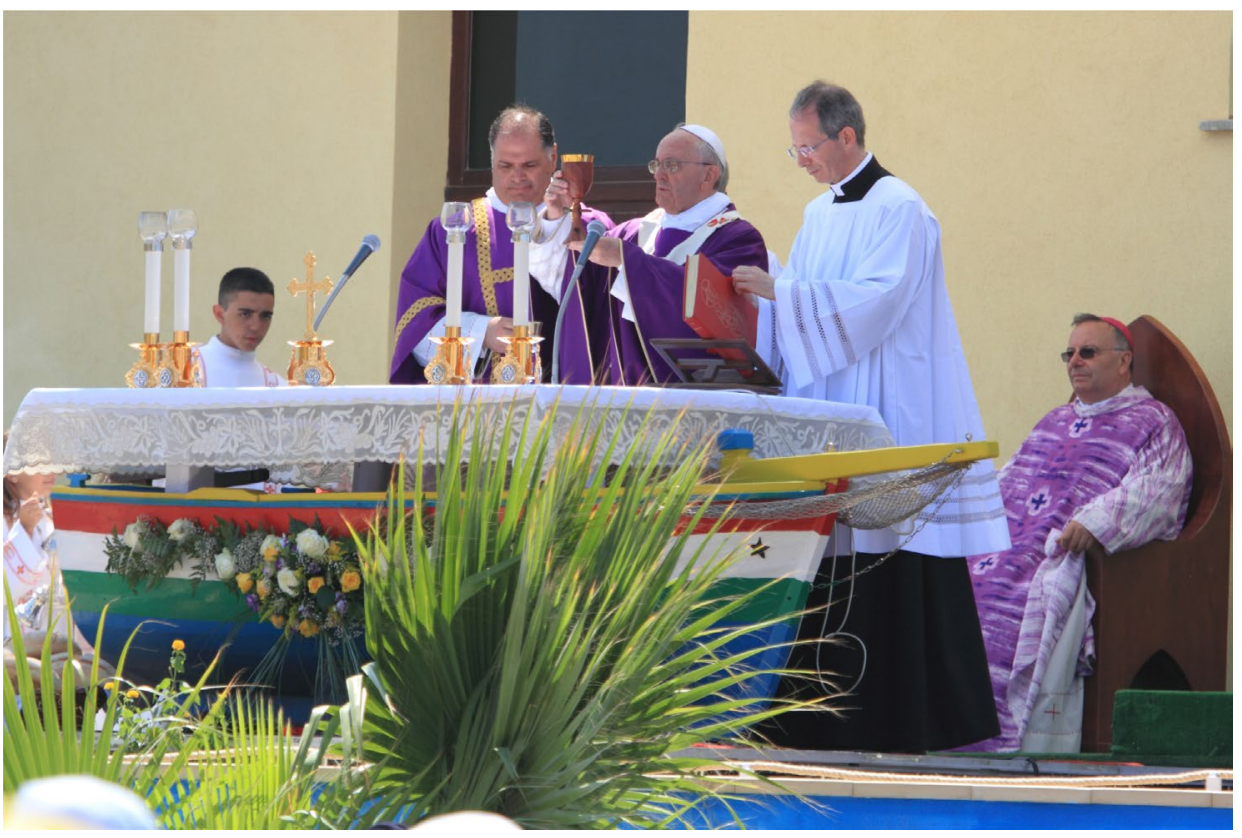

FIGURE 4 The altar in use during Pope Francis' Mass at Lampedusa. Photograph taken 8 July 2013, by Pietro Tuccio.

Just three or four days before they shipwrecked, this wooden boat with about 530 migrants aboard left the port of Zwara in Libya. Though Lampedusa is approximately I 80 miles north of here, boats are not always led by someone who knows how and where to navigate. Survivors recounted that they discovered they had been going in the wrong direction, towards Tunisia in the west. They were then accompanied for a time by a Tunisian fishing boat who pointed them in the proper direction. However, they veered northeast this time and discovered they were nearer Malta and had missed Lampedusa. Escorted by Maltese vessels, they turned around and headed west to Lampedusa. ${ }^{59}$ It was at this point that they were rescued by the Italian Guardia di Finanza. ${ }^{60}$ Three authorities were on board the boat as they guided it into Lampedusa's port, accompanied by GdF vessels. Just before docking, the rudder broke, the boat veered right, and crashed into the rocks and cliffs nearby. The boat precipitously tipping, migrants jumped into the water and tried to climb up the rocks to safety. Meanwhile, Coast Guard, GdF, police, and human rights personnel who had been waiting at the port to assist with disembarkation ran to the cliffs, forming a human corridor to assist migrants up the rocks. Most of these migrants were from sub-Saharan Africa or migrants that had been living and working in Libya for some time. When the NATO bombings began, they were forced to flee.

The next morning, Lampedusans were happy to have heard of the safe rescue of all the migrants. Many took pictures and spread them on social media and went to the area

59 'Lampedusa: Migranti salvati da catena umana; Tre cadaveri vicino agli scogli', (8 May 20II) L'Unità < http://www.unita.it/italia/la mpedusa-migranti-salvati-da-catena-umana-br-tre-cadaveri-vicino-agli-scogli-I.290939> [accessed 20 December 2013].

60 Customs and Finance, which also receives monies and operates as part of Frontex. 
in front of the campo sportivo to play with the children. It was only after two days that three bodies were discovered under the boat, three migrants who could not be saved. Tuccio was very touched by this event and the deaths of those three migrants. Every morning, he would walk down to the port and see the boat, still stuck in the rocks, sad for that loss of life.

Poi un giorno non c'era più [...] Il mare se l'ha riportata di nuovo, perché la mareggiata l'ha rialzata e se l'ha riportata. È rimasto un pezzo bello grosso, circa un metro e mezzo di lunghezza, un diametro I $2 \mathrm{~cm}$, I2 per I2, insomma un bel pezzo molto pesante. Cosi l'ho portato in falegnameria, e di la mi è venuta questa, l'ispirazione di poter fare questi calici particolari che ricordassero anche questa barca e tutta quella gente che ha portato sulla costa, in vita.

Tuccio was troubled by the death of these migrants and would visit the boat, a sort of memorial of their lives, journeys, and death, each day. When the sea took back the boat, it left him a tangible memory. His inspiration was not merely artistic, but religious and memorial in nature. He made four chalices from that wood. One he gave to the local parish priest, and the rest he kept for himself, unable to give them away: 'molti le volevano, questi calici, molti preti, che venivano da me, che vogliono conoscere la storia, poi vedono questi calici, e io non le davo a nessuno perché erano miei, come effetto, come ricordo di quella storia'. The chalices were a part of him in a way, just like they were a part of the story of all those migrants who survived, and those who did not.

When news of the Pope's visit to the island reached Tuccio, via the parish priest, he was asked to help construct the various liturgical objects. And then, if he would give one of his chalices to the Pope. He could not refuse, and a photo was taken of the three and sent to Rome. The Pope chose what Tuccio considers the most special chalice, the one with the nail through the stem (Figures 5 and 6). This chalice was especially meaningful for him:

E volutamente ho studiato il chiodo per poterlo inserire di nuovo per rappresentare anche un po' la crocifissione, diciamo, su quel calice [...] E cosi il papa l'ha scelto il calice con il chiodo, ed ha celebrato la messa a Lampedusa con quel calice. E la storia è molto bella, diciamo, anche perché porta in memoria di questa cosa, di tutte quelle persone che si sono salvati. Non c'è più un ricordo di quella barca. Vive solo quel pezzo di legno che sono questi calici. Non c'è più nulla.

For Tuccio, the nail in the wood must become part of the chalice; they were inextricable. The nail referenced Christ's crucifixion - his suffering to redeem all mankind. And that this representation was attached to an object meant to memorialize and re-enact that sacrifice during the Mass, by holding the precious blood of Christ, links migrant stories of migration evermore to a Christian theological narrative. For Tuccio, as Tilley explains, this material object was a metaphorical medium through which he - and after the Mass, all who participated in its use - could reflect on their world. ${ }^{6 r}$

The migrants were transferred from Lampedusa to the mainland. Their presence can no longer memorialize the shipwreck. Their experiences - searching for the right state, of wandering in the water, of being assured of safety only to have it taken away in a

61 Christopher Tilley, 'Objectification', in Handbook of Material Culture, ed. by Christopher Tilley and Webb Keane (London: SAGE Publications Ltd., 2006), pp. 60-73 (62). 


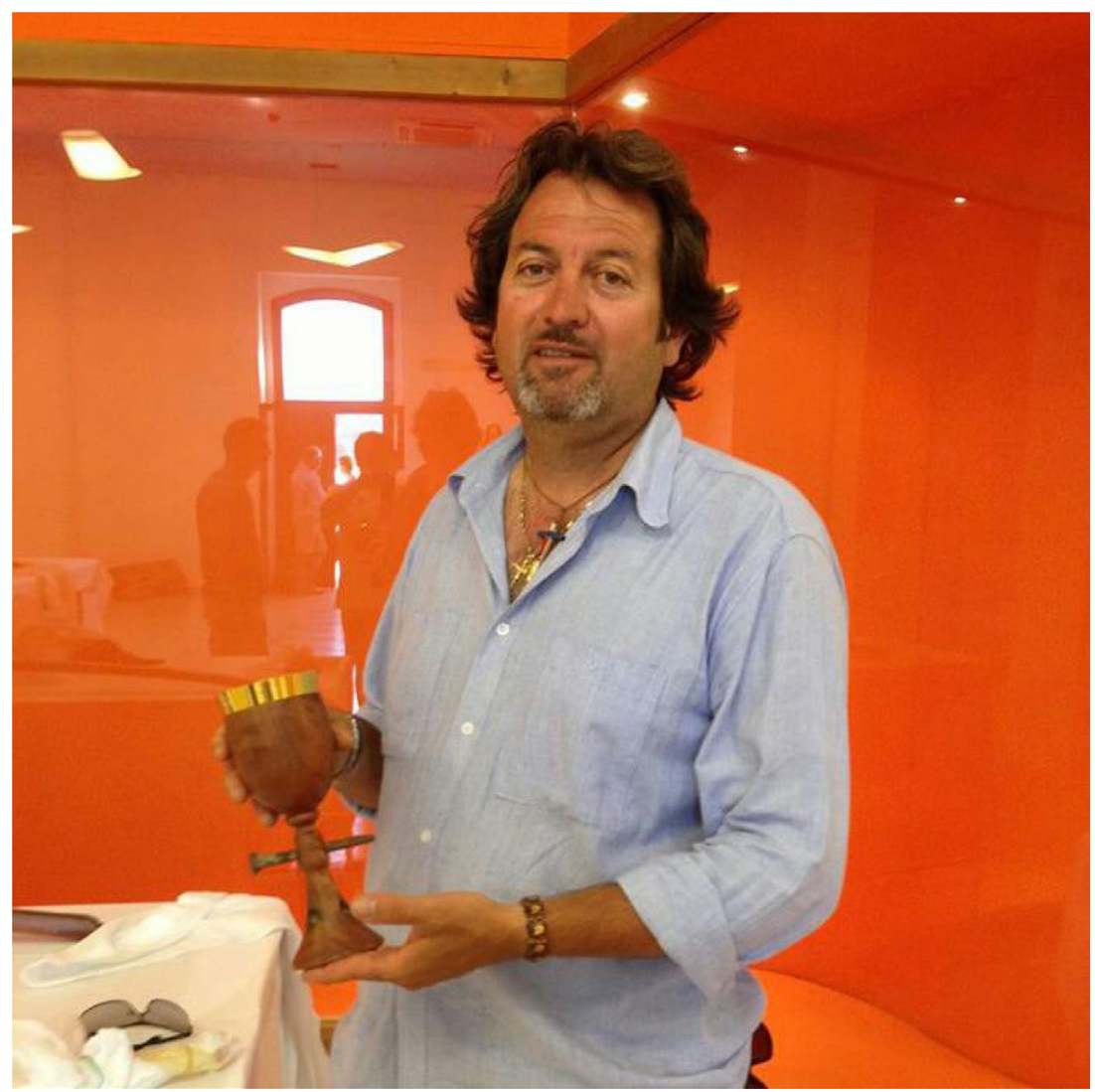

FIGURE 5 Francesco Tuccio with the chalice he carved from the boat that shipwrecked on Lampedusa's coast in May 2011. Image courtesy Francesco Tuccio.

moment when the boat crashed, of fearing death when the ship tipped and threatened to capsize, of finally obtaining safety on the rocky shore - are assembled onto this chalice. In holding the blood of Christ as Pope Francis consecrated the bread and wine, the chalice also held the blood of migrants, of those who did not survive. It pointed to their suffering, as Christ suffered during the crucifixion, but also to their re-birth, as Christ was resurrected and they were brought to safety.

As I spoke with Tuccio about his experiences of creating these objects, participating in the Mass, and meeting the Pope, I noticed at times he could not quite explain in words his emotions about these events. He repeated often, 'mi ha colpito tantissimo.' The shipwreck, the plight of migrants in general, the Pope's homily, the participation in this momentous Mass. As Pinney argues, not everything can be represented by language. ${ }^{62}$ It often falls short when dealing with human tragedy and emotion. These objects, then, represent a moment and place. They bump up against the borders of what is knowable

${ }_{62}$ Christopher Pinney, 'Four Types of Visual Culture', in Handbook of Material Culture, ed. by Christopher Tilley and Webb Keane (London: SAGE Publications Ltd., 2006), pp. I3I-44 (I37). 


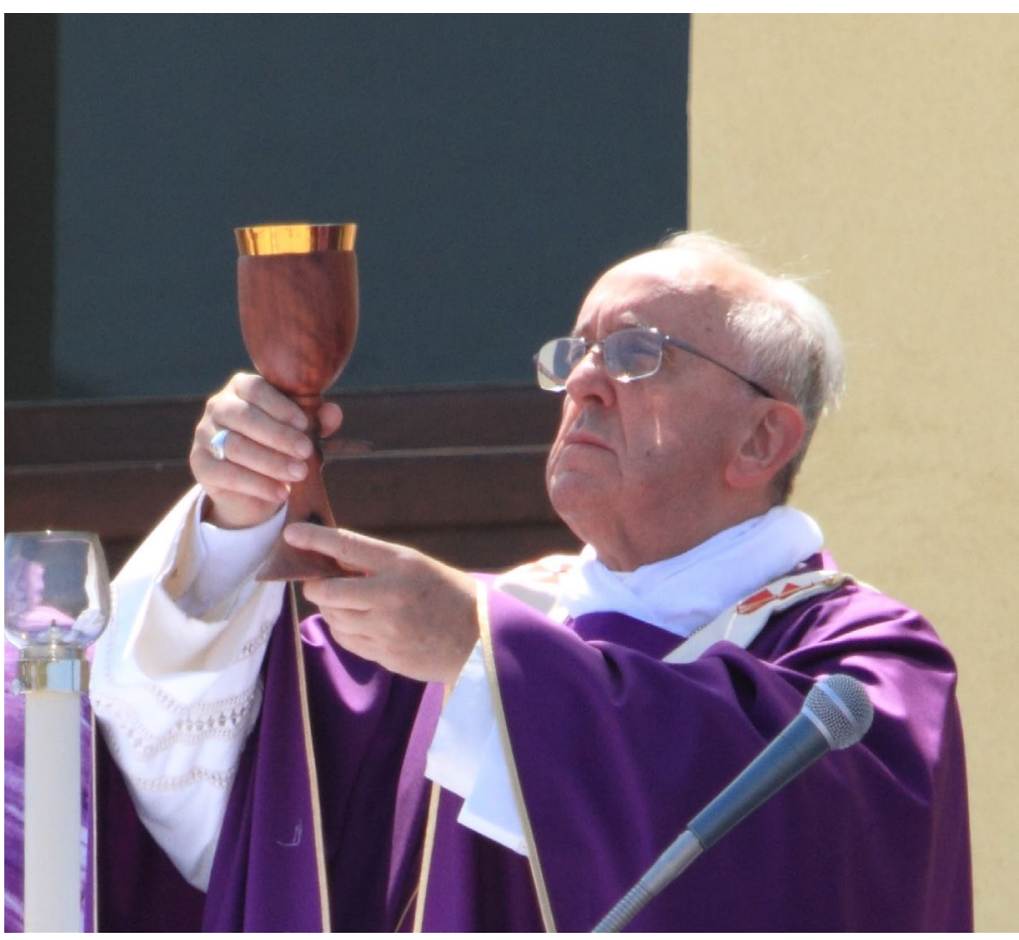

FIGURE 6 Pope Francis raises the chalice made by Tuccio during the consecration of the wine at Mass. Photograph taken 8 July 2013, by Pietro Tuccio.

and effable through experience and that which transcends complete human understanding and must be a part of the religious.

\section{Conclusions}

In choosing Lampedusa, a tiny island closer to Africa than Italy or the rest of the EU, for his first apostolic visit, Pope Francis made a multitude of statements. He celebrated a penitential Mass, calling on a global community to seek forgiveness for the deaths and sufferings of all migrants. His trip was not full of pomp and circumstance, reminiscent of the 20 I I visits from Berlusconi and Angelina Jolie. ${ }^{63}$ He used a borrowed jeep, asked the town to make no special preparations or spend any money. He prayed for the migrants who had lost their lives and chose to enter Lampedusa in the same humble way they often do, on a Coast Guard vessel.

Through the liturgical objects used during Mass, he communicated his oneness with the plight of migrants. By choosing Lampedusa, he centres the geographical margins. He brings to the centre of Catholic teaching the bodies of migrants and calls for their bodies to be centralized also in Catholic practice. The ferula, ambo, altar, and chalice

63 Giangravè, 'La visita a Lampedusa era di Gutierrez, non della Jolie'; La Repubblica, 'Berlusconi show at Lampedusa; "Entro 48-60 ore isola liberata". 
served as visual reminders of migrant suffering during the Mass. Yet they also signified transformation and rebirth in Christ. Those who viewed the Mass live or online, and those who participated in person, were reminded by these objects to remember the suffering of those outside themselves and take up the challenges in Pope Francis' homily. The marginalized, wounded, migrant body was centred, enfolded into the larger Body of Christ, through the Pope's use of these particular objects and his accompanying speech during the homily.

By tracing the always partial stories of the wooden boats, whose use varied from a vessel of trafficking, of hope, of danger, of new life, to discarded trash, I have chosen to highlight their transformation. Once discarded, they are now sacred, liturgical objects. They remain in Lampedusa's church, a reminder of the Pope's visit and his words.

In challenging the anonymity of state and bureaucratic decisions that affect migrant lives and deaths, Pope Francis challenged the notion of the Italian state as distanced from migrants. He placed the responsibility squarely on the shoulders of the state, specifically on decision makers. He called on all individuals to weep for the deaths of migrants and to change their hearts and actions so that these tragedies do not recur.Pope Francis peopled the state, he recognized it as embodied, and saw that embodiment as a space to resist indifference. He challenges a notion of the Italian state which does not include migrant bodies and migrant histories. And some of those in power have listened. António Guterres, High Commissioner of Refugees for the UN, stated that EU politicians should follow the Pope's example of accoglienza, saying 'i decisori politici ascoltino le parole e seguano l'esempio che Papa Francesco ha dato in modo così eloquente con le sue parole, ma soprattutto con la sua visita a Lampedusa.' ${ }^{64}$

Pope Francis stayed on the island less than a day, and yet his mark on Lampedusa, and Lampedusa's mark on him, have remained. He has continued to pray publically that migrants in the squalid detention centres may be transferred quickly, despite all the forms and bureaucracy required. ${ }^{65}$ He has sent supplies to those in the Lampedusa centre. Just a few weeks after he left, a group of migrants left the centre in Lampedusa to protest their fingerprinting and Dublin II Regulations. ${ }^{66}$ They chose the piazza in front of the Church, not the town hall, for their protest.

His visit and all the specific choices he made in the celebration of Mass worked to create a space where religious faith and politics could meet. A space that enabled a new way for migrants to engage the state, through religion. A space of inclusion for migrant voices, where, it is to be hoped, suffering can lead to something better. The migrants who protested on the steps of Lampedusa's church, though perhaps a small act of resistance, staked their claim for a new life in the EU on their own terms. They staked a claim for migrant agency and freedom of movement. For they are tired of EU and Italian restrictions that decide when they leave the island, where they can and cannot go, and a system that exploits their labour and bodies, but does not value their God-given human dignity.

\footnotetext{
${ }^{64}$ Luca Liverini, 'Guterres: la UE ascolti il Papa, accolga i rifugiati', (7 December 20I3), Avvenire.it, <http://www. avvenire.it/Mondo/Pagine/guterres-europa-ascolti-il-papa-e-accolga-i-rifugiati.aspx> [accessed 2I December 20I3].

65 See Vatican TV, Pope's General Audience - Udienza Generale del Papa - 2013-10-09.

66 Associazione Askavusa, 'Sulla protesta dei migranti a Lampedusa', (24 July 2013), MeltingPot.org, < http://www.meltingpot.org/Sulla-protesta-dei-migranti-a-Lampedusa.html> [accessed 2I December 20I3].
} 


\section{Acknowledgements}

The author gratefully acknowledges comments and support on this paper from Azra Hromadzic and Nicole Nguyen. Many thanks to Luciano Baracco for organizing this special issue and two anonymous reviewers for their comments. 